\begin{tabular}{|c|c|}
\hline & $\begin{array}{l}\text { International Journal of Trend in Scientific } \\
\text { Research and Development (IJTSRD) }\end{array}$ \\
\hline 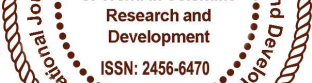 & International Open Access Journal \\
\hline 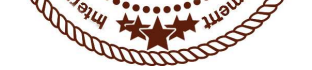 & ISSN No: 2456 - 6470 | www.ijtsrd.com | Volume - 2 | Issue - 2 \\
\hline
\end{tabular}

\title{
A Study of Impact of GST on Leather Industries in India
}

\author{
Shailja Singh \\ Research Scholar, Department of Commerce and Business \\ Management, Integral University Lucknow, Uttar Pradesh
}

\begin{abstract}
Leather is one of the most traded commodities in the world. The leather industry occupies a prominent place in Indian economy due to substantial export earnings. The Indian Leather industry accounts for around $12.93 \%$ of world's leather production of hides and skins. The country ranks second in terms of footwear and leather garments production in the world and accounts for $9.57 \%$ in world's footwear production.
\end{abstract}

\section{INTRODUCTION}

- The Leather sector is known for its consistency in high export earnings and it is among top ten foreign exchange earners of the country.

- With an annual turnover of US\$12 billion the export of leather and leather products increased manifold over last decades and touched US\$ 5.6 billion in year 2016-17 recording a cumulative annual growth rate of about $3.09 \%$ (5years).

- The Indian leather industry is bestowed with an affluence of raw materials as India is having 20\% of the world cattle and buffalo and $11 \%$ of world goat and sheep population.

- The leather industry is employment intensive sector providing job to about 3 million people mostly from the weaker sections of the society.

- India is the second largest producer of footwear and leather garments and third largest producer of saddlery in the world.

- The major production centers for leather and leather products in India are located in the states of Tamil Nadu- Chennai, Ambur, Ranipet, Vaniyabadi, Vellore, Pernambut, Trichy, Dindigul and Erode; West Bengal-Kolkata; Uttar Pradesh-
Kanpur, Agra, Saharanpur, Noida; MaharashtraMumbai; Punjab- Jalandhar; KarnatakaBangalore; Andhra Pradesh- Hyderabad; HaryanaAmbala, Gurgaon, Punchkula, Karnal, Faridabad, Delhi; Madhya Pradesh- Devas; Kerala- Calicut, Ernakulum; Rajasthan- Jaipur; Jammu\& KashmirSrinagar.

\section{EXPORT HIGHLIGHTS}

- Sotal leather and leather goods exported from India stood at US\$ 1.42 billion during April-June 2017 as against $\$ 1.43$ billion in the corresponding quarter of Year 2016.

- The major markets for Indian leather products during Apr-Jun 2017, were US (14.66 per cent), Germany (11.22 per cent), UK (10.05 per cent), Italy (7.03 per cent), Spain (4.63 per cent), France (5.15per cent), Hong Kong (4.52 per cent), UAE (5.04 per cent), China (3.09 per cent), Netherlands (3.05 per cent), Poland (2.23 per cent) and Vietnam 1.88 (per cent).

At 47.54 per cent, footwear (leather and nonleather) and footwear components accounted for the lion's share of leather exports in April-June 2017, followed by leather goods and accessories with 23.34 per cent share, finished leather with 16.77 per cent share, leather garments with 9.79 per cent share and saddlery \& harness with 2.56 per cent share.

\section{GST IN INDIA AND ITS ADVANTAGES}

GST (Goods and Service Tax) is an indirect tax which has replaced many indirect taxes in India. The Goods 
and Service Tax Act was passed in Parliament on $29^{\text {th }}$ March 2017. The Act came into effect on July $1^{\text {st }}$ 2017.

In simple word we can say that GST is a tax that is levied on the consumption that is enforced on manufacture sale and consumption of goods and services at national level. This kind of tax will remain same for all indirect tax levied by state and central government. It is a noteworthy consideration that after introduction of GST some tax like income tax, export tax, corporate tax including capital gain tax will not be affected in any manner. GST will incorporate of

- Centre will levy CGST which is known as Central GST.

- State will levy SGST which is known as State GST.

- Lastly the Integrated GST (IGST) that can be will be charged by central government on inter-state supply of goods and services.

\section{- Removing cascading tax effect}

Higher threshold for registration

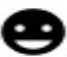

Composition scheme for small businesses

$\Theta$

Online simpler procedure under GST

- Lesser compliances

- Defined treatment for e-commerce

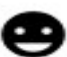

Increased efficiency in logistics

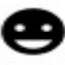

Regulating the unorganized sector

Source: https://cleartax.in/s/gst-law-goods-and-services-tax\#adv

\section{METHODOLOGY}

The present study is based on secondary data. The data has been collected from Council for Leather Exports, GST Guide Book and Ministry of Commerce and Industry.

\section{RATE OF GST (GOODS AND SERVICE TAX) PAYABLE FOR LEATHER, SKINS, RAW HIDES ETC IN INDIA}

$>$ GST Rates for leather and leather products are defined under chapters 41 and 42 respectively of HSN Code of GST Guide.

$>$ GST Rates for Leather Skins and Raw Hides

$>$ All goods under chapter 41 of HSN code pertaining leather, raw hides and skin attract GST at $5 \%$ and $12 \%$.

$>$ Leather and Raw Hides attracting 5\%
- Raw hides and skins of bovine (including buffalo) or equine animals (fresh, or salted, dried, limed, pickled or otherwise preserved, but not tanned, parchment dressed or further prepared), whether or not dehaired or split.

- Raw skins of sheep or lambs (fresh, or salted, dried, limed, pickled or otherwise preserved, but not tanned, parchment dressed or further prepared), whether or not with wool on or split.

- Other raw hides and skins (fresh, or salted, dried, limed, pickled or otherwise preserved, but not tanned, parchment dressed or further prepared), whether or not dehired or split.

- Tanned or crust hides and skins of bovine (including buffalo) or equine animals, without hair on, whether or not split, but not further prepared.

- Tanned or crust hides and skins of other animals, without wool or hair on, whether or not split, but not further prepared.

- Raw hides, skins, tanned or crust hides and skins, not further prepared. 
Leather hides attracting $12 \%$ GST

- Leather further prepared after tanning or crusting, including parchment-dressed leather, of bovine (including buffalo) or equine animals, without hair on, whether or not split.

- Leather further prepared after tanning or crusting, including parchment-dressed leather, of sheep or lamb, without wool on, whether or not split.

- Leather further prepared after tanning or crusting, including parchment-dressed leather, of other animals, without wool or hair on, whether or not split.

- Chamois (including combination chamois) leather; patent leather and patent laminated leather; metalized leather.

- Composition leather with a basis of leather or leather fiber, in slabs, sheets or strip, whether or not in rolls; parings and other waste of leather or of composition leather, not suitable for the manufacture of leather articles; leather dust, powder and flour.

- LEATHER GLOVES SPECIALLY DESIGNED FOR USE IN SPORTS IS TAXED AT $12 \%$ GST, TRAVEL GOODS, HANDBAGS AND OTHER LEATHER PRODUCTS ARE TAXED AT 28\% GST.

IMPACT OF GST ON LEATHER INDUSTRY AS PER THE REPORTS FROM COUNCIL FOR LEATHER EXPORTS (OCTOBER, 2017)

- According to the Council for Leather Exports the levy of IGST (Integrated Goods and Service Tax) is affecting the liquidity of exporters and blunting their competitive ages.

- CLE (Council for Leather Exports) has suggested the government to provide IGST exemption on imports of raw materials and capital goods in making products for exports.

- CLE also demanded reduction of GST on finished leather from $12 \%$ to $5 \%$ as these are essential material for the sector.

- CLE also asked for cut in GST rates for leather gloves and garments from $28 \%$ to $12 \%$ so as to attract FDI (Foreign Direct Investments) in this sector.

- CLE also added that "Loss of competitiveness due to GST issue will be huge loss to the industry which currently has an annual export turnover of
USD 5.6 billion and employment of about 4.5 billion with predominant women employment.

- CLE also said that the industry is facing financial burden and significant outflow of capital on account of levy of higher GST rates on major segments of the manufacturing chain and requirement of upfront payment of GST and then claim refund.

- CLE also claimed that upfront payment of GST and delayed refunds not only increases the transaction cost of the exporters but also threatens to wipe out the small and medium exporters who do not have the resources for generating significant money for GST payment.

- The Council has also requested the government for reduction of job work for the manufacture of leather products and footwear from $18 \%$ to $5 \%$ as done for textile sector. The $18 \%$ GST on job work has led to job losses of several job workers.

- CLE has also requested the government for reduction of GST on Common Effluent Treatment Plants (CETPs) from $18 \%$ to 5\%. CETPs were earlier exempted from service tax charges the CLE has also called for the reduction of GST on leather goods, gloves and garments from $28 \%$ to $12 \%$ so as to promote FDI (Foreign Direct Investment) in this sector.

- According to Mukhtarul Amin chairman of CLE (Council for Leather Exports) said that" The Leather Exports from India is at around \$6billion and we are facing severe competition from countries like Bangladesh where the industry has several incentives if the issues related to GST are not addressed now the exports may come down by 15\%-20\%".

- Adesh Gupta chairman of CFLA (Council for Footwear, Leather and Accessories) said that the footwear sector is highly affected by GST because the prices of the products were increased by $5 \%$ $7 \%$ due to $18 \%$ GST rates on these products.

\section{RESULTS AND CONCLUSIONS}

From the above data we can conclude that the current situation is threatening to take away the business of Indian leather industry to the countries like Bangladesh, Vietnam and Indonesia. The industry is also facing worldwide recession and fresh challenge in the form of emergence of strong production centers in Eastern Europe. Loss of competitiveness due to GST issues, will be a huge loss to the leather industry which currently has an annual export turnover of $\$ 5.6$ 
billion and employment of about 4.5 million, with predominant women employment.

Thus, from the above study we can say that GST has a negative impact on Leather Industry and there is an urgent need for government interventions in order to protect the interests of the leather industry and to achieve envisaged 10 percent export growth.
DATA

AVAILABE

ON:

WWW.INDIAFILINGS.COM/LEARN/GST-RATELEATHER-LEATHER-PRODUCTS

1. www.seair.co.in/hs-codes/chapter-41-raw-hidesskins-furskins-leather.aspx

\section{REFRENCES}

1. https://www.ibef.org/exports/leather-industryindia.aspx

2. https://retail.economictimes.indiatimes.com/news/ industry/leather-industry-seeks-governmentsintervention-on-gst-issues/60936087

3. https://cleartax.in/s/raw-hides-skins-leather-gstrate-hsn-code

4. http://www.livemint.com/Industry/5jwZeq7GEAX 2O5qwRnd4aK/GST-rates-Footwear-to-costmore-as-firms-look-to-hike-price.html

5. http://www.businessstandard.com/article/economy-policy/leatherexports-may-dip-by-20-if-gst-related-issues-gounheeded-cle-117092600872_1.html

6. http://www.businesstoday.in/current/economypolitics/gst-refund-exports-jump-novemberexport-data-india-exporters/story/266103.html

7. http://commerce.gov.in/

8. http://leatherindia.org/ 